\title{
PREGNANCY DIAGNOSIS
}

\author{
G.W. DYCK
}

Animal Science Section, Agriculture Canada Research Station, Brandon, Manitoba, Canada

The diagnosis of pregnancy in the pig has taken several diverse forms involving tests for the presence of the products of conception or tests for the absence of oestrous activity. Thus, some tests determine specifically that the animal is pregnant while others indicate that she is not pregnant. The methods currently available to confirm pregnancy or non-pregnancy are effective only after the beginning of the expected time of implantation, with accuracy of the diagnosis increasing with time after mating. In some animals it may be necessary to employ two or three different tests to obtain an accurate diagnosis. Excluding disease problems which may result in death of the entire litter, the accuracy of pregnancy confirmation approaches $100 \%$ by the end of the second trimester. In contrast, the accuracy of detection of the non-pregnant female is extremely variable and dependent on the nature of the reason(s) for her failure to become pregnant. of:

The problems of pregnancy diagnosis may be divided into the three areas

(1) Early confirmation of pregnancy,

(2) Detection of the non-pregnant females,

(3) Rapid 'on farm' confirmation of pregnancy and detection of nonpregnant animals.

Thus, the desired system of pregnancy diagnosis is one that can be operated by the farmer and will confirm pregnancy or non-pregnancy by day 18 after mating. While such a system is not available currently, extensive progress has been made in the last ten years.

\section{Pregnancy diagnosis during the pre-implantation stage}

Starting with fertilization of the ova, the developing conceptuses secrete specific biochemical messengers that indicate their presence to the host female. A relatively complete review of the subject has been made by Dickmann, Dey and Sen Gupta (1976). These chemicals are probably closely related to the suppression of immunorejection, to blastocyst growth and later to the maintenance of pregnancy. This assumption is based on observations that blastocysts may be transferred into cycling females only up to eight days after oestrus (Hunter, Polge and Rowson, 1967) and that 
embryos must be present in both uterine horns between days 10 and 12 (Dhindsa and Dziuk, 1968) for the maintenance of pregnancy. Therefore any diagnostic parameters that could be used before day 8 would identify the presence of the conceptuses while after day 8 detection of the implanted embryos is possible (pregnancy).

At the present time, there are no readily identifiable parameters in the pig for the diagnosis of pregnancy during the pre-implantation stage of development. Changes have been observed in the metabolism of progesterone with an increase in urinary levels of $5 \beta$-pregnan-3 $\alpha$ ol-20-one and $5 \beta$-pregnan-3 $\alpha 6 \alpha$-diol-20-one (Tillson, Erb and Niswender, 1970). Further research is required to determine if these changes in progesterone metabolism could constitute an effective method of pregnancy diagnosis or if there are other hormonal changes that could be used. In the mouse (Morton, Hegh and Clunie, 1976) and sheep (Evinson et al., 1977; Nancarrow et al., 1980) specific pregnancy-associated immunosuppressive activity has been observed in plasma by four hours after fertilization. In the pig similar immunosuppressive activity has been observed $(\mathrm{H}$. Morton, personal communication). Further research is required to confirm its efficacy as a very early pregnancy diagnosis.

\section{Pregnancy diagnosis during embryonic and foetal development}

Blastocysts elongate and begin the process of implantation about twelve days after mating. The hormonal interrelationships involved and the nature of their action are discussed in Chapters 12,13 and 14. The resulting growth of the uterus and embryos, the failure to exhibit oestrus, and the changes in hormone levels in the blood all provide accurate means for the detection of pregnancy.

\section{BLOOD PROSTAGLANDINS}

Recently, the determination of blood concentration of prostaglandins by radioimmunoassay has been suggested as an accurate means of pregnancy diagnosis (Martinat-Botte et al., 1980). This procedure is based on the observation of Bazer and Thatcher (1977) that viable embryos prevent the secretion of prostaglandins into the uterine vein between the eleventh and sixteenth day of the cycle. Thus, low blood levels of prostaglandins at this time should be indicative of pregnancy. In an experiment using 389 sows with blood samples collected on day 13,14 or 15, Martinat-Botte et al. (1980) reported an accuracy of $90 \%$ in diagnosing 292 of the sows pregnant. They also reported an accuracy of $68 \%$ for the detection of the remaining 97 non-pregnant sows.

The failure to detect $10 \%$ of the pregnant sows and the low accuracy of detecting non-pregnant sows suggests that further research is required to determine the efficacy of this procedure as a means of early pregnancy diagnosis.

\section{LAPAROSCOPY}

For the detection of pregnancy, direct observation of the reproductive tract by laparoscopy provides the earliest accurate diagnosis. In the technique as 
described by Wildt et al. (1973) the gilt is placed head down and supine on a $30^{\circ}$ sloped table with the hind legs loosely tied in a vertical position. After surgical preparation, a trocar and cannula are inserted along the mid-line just anterior to the position of the ovaries. The trocar is then withdrawn and a $5 \mathrm{~mm}$ laparoscope inserted. A tactile probe for manipulation of the internal organs is inserted about $10 \mathrm{~mm}$ lateral to the laparoscope and the abdominal cavity insufflated with $5 \% \mathrm{CO}_{2}$ in air. The entire procedure takes 30-45 minutes. Wildt, Morcom and Dukelow (1975) reported a $100 \%$ accuracy in pregnancy diagnosis by the end of the second week after mating. Differences between pregnant and non-pregnant gilts were observed in uterine colouration as a result of increased blood flow to the uterus and in uterine contractions as a result of hormonal stimulation. Changes in luteal regression were observed as early as day 13 , and by day 16 differences in follicular development were apparent. Laparoscopy had no effect on foetal survival. While no observations have been reported on the effect of an extended luteal phase on pregnancy diagnosis, the utilization of both uterine colouration differences and ovarian morphology suggests that these animals would be correctly diagnosed as non-pregnant. Other abnormalities such as cystic ovaries, ova-testes and anoestrous sows would be detected and thus culled from the breeding herd. Non-pregnant animals could be mated again at the next oestrus. The only animals that would not be accurately diagnosed are those with late embryonic death.

Laparoscopy, while accurate for the diagnosis of pregnancy, is probably only applicable to research situations. The time involved for each animal, the cost of equipment and the need for personnel trained in surgical procedures all combine to make the technique uneconomical.

\section{BLOOD PROGESTERONE}

The analysis of blood, collected between days 17 and 24 after mating, for progesterone concentration has been found to provide a relatively accurate means of diagnosing pregnancy (Robertson and Sarda, 1971; Meyer, Elsaesser and Ellendorff, 1975). A small sample of blood (1ml) is collected from the pig and the plasma analysed for its progesterone concentration using either competitive protein binding or radioimmunoassay procedures. A sow is deemed to be pregnant if the plasma concentration of progesterone is greater than $5 \mathrm{ng} / \mathrm{ml}$. Stabenfeldt et al. (1969) have observed plasma progesterone concentrations of less than $5 \mathrm{ng} / \mathrm{ml}$ from four days before to three days after the first day of oestrus. In ovariectomized gilts, Ellicot and Dziuk (1973) reported that the minimum daily progesterone requirement for the maintenance of pregnancy was $28.6 \mathrm{mg}$ which corresponded to a plasma concentration of $6 \mathrm{ng} / \mathrm{ml}$. Pregnancy. was not maintained at a plasma concentration below $4 \mathrm{ng} / \mathrm{ml}$. Thus, progesterone as a means of pregnancy diagnosis relies on the maintenance of corpus luteum function rather than pregnancy although the two are usually analogous.

In their initial observations Robertson and Sarda (1971) reported an accuracy of $88 \%$ for diagnosing pregnancy in 25 sows. The three sows wrongly diagnosed as pregnant had oestrous cycles of 28,37 and 40 days. In a larger population of animals Williamson, Hennessy and Cutler (1980) 
reported an accuracy of $97 \%$ for confirming pregnancy in 217 sows and $60 \%$ for detecting 136 non-pregnant sows. This was a herd with reproductive problems and a further evaluation of the results revealed that the 17 sows with a 'normal' oestrous cycle length were detected. Only $54 \%$ of the sows with a delayed return to oestrus were detected. The remaining $46 \%$ all had progesterone concentrations similar to those of pregnant sows. In large scale commercial application to 9920 sows the accuracy of pregnancy confirmation was $92 \%$ while the detection of non-pregnant sows was $99 \%$ (MacNeil, 1979).

Thus, blood progesterone analysis has a definite place as a method of pregnancy diagnosis. In the current commercial application blood samples are collected on day 17 , the samples analysed on day 18 or 19 and the results sent back to the producers on day 21 when the open sows could be expected to be in oestrus (MacNeil, 1979). The technique is limited by the need to collect blood samples and the proximity of a laboratory to conduct the analysis. The accuracy of the results for detecting non-pregnant animals is limited by the occurrence of longer or shorter than normal oestrous cycles and late embryonic death. The failure to detect all pregnant sows can be attributed to the occasional sow that has a low blood progesterone concentration.

\section{OESTRUS DETECTION}

The failure of the sow to return to oestrus after mating is the most widely used method of diagnosing pregnancy. The value of this technique is based on the knowledge that essentially all pregnant sows will not exhibit oestrus during pregnancy while non-pregnant sows may be expected to return to oestrus between 18 and 25 days after the previous oestrus. Oestrus is confirmed when the sow will assume the 'standing reflex' posture. However, this posture does not always occur in all sows in the absence of a boar regardless of other stimuli such as back pressure, boar odour, boar sounds, or a boar in an adjacent pen (Signoret, 1970). Thus, the physical presence of a boar is the most accurate method of oestrus detection and the confirmation of non-pregnancy. The use of oestrogenic preparations (Nishikawa, 1953) or androgen-oestrogen preparations (Jöchle and Schilling, 1965) have been recommended as an aid to stimulating oestrus in non-pregnant sows. Bosc, Martinat-Botte and Nicolle (1975) found no improvement in the detection of non-pregnant sows following the injection of androgen-oestrogen preparations.

Although widely used for pregnancy diagnosis there are very few reports on the value of oestrus detection as a diagnositic tool. Bosc, Martinat-Botte and Nicolle (1975) reported an accuracy of $39 \%$ for the detection of oestrus in 154 non-pregnant sows between 19 and 25 days after insemination. The 94 non-pregnant sows not detected in oestrus comprised $9.6 \%$ of the total animal population. The reason for the low rate of oestrus detection is that the sows were not in oestrus at the times of checking. There are many reasons for the failure of the animals to be in oestrus. Several reports (Pásztor and Tóth, 1964; Signoret, 1967; Dyck, 1971) have indicated that between 7 and $25 \%$ of the oestrous cycles are outside the 18-25 day 
range. In addition, sows with silent oestrus or cystic ovaries, anoestrous sows, and sows with late embryonic death, etc. would not be detected. Continued daily checking for oestrus would eventually detect all of these sows but it is extremely time-consuming.

\section{VAGINAL BIOPSY}

The initial observations that the histological structure of the vaginal epithelium of the sow showed cyclical changes were made by McKenzie (1924) and Wilson (1926). The utilization of these changes as a tool in pregnancy diagnosis was first recommended by Ciurea et al. (1955). The tissue sample for analysis should be collected from the dorsal or lateral wall of the vagina approximately $8 \mathrm{~cm}$ back from the cervix and then immediately frozen or fixed in formalin for transport to the laboratory for analysis. Standard techniques for the histological examination of frozen or fixed tissues all provide results of equal accuracy (Diehl and Day, 1973). During proestrus, mitosis and cellular proliferation commence with growth continuing during oestrus when a depth of 5-20 epithelial cells may be observed. During metoestrus a sloughing of the outer cell layers occurs and continues until a $3-5$ cell depth is reached. During dioestrus the cell depth remains at 3-5 cells. In the pregnant sow the same changes occur as are found from oestrus through to dioestrus. However, as pregnancy progresses there is a further sloughing of cells to a depth of 2-3 cells by day 22 . The differences in the vaginal epithelium of pregnant sows and cycling sows during proestrus, oestrus or metoestrus (days 18-25 after mating) provide an accurate means of pregnancy diagnosis (Morton and Rankin, 1969). Thus, this method of pregnancy diagnosis is based on the absence of oestrous cycle activity.

In a review of the results published between 1963 and 1970, Walker (1972) reported the accuracy of pregnancy confirmation at between $94 \%$ and $100 \%$ and the accuracy of detecting non-pregnant animals at between $50 \%$ and $100 \%$. Examples of more recent studies are shown in Table 15.1. Bosc, Martinat-Botte and Nicolle (1975) found no difference between days in the ability to correctly diagnose pregnancy. However, in the nonpregnant sows the accuracy of the diagnosis increased with time after mating. Among sows with a normal return to oestrus (days 18-25), 81\% were correctly diagnosed compared with $69 \%$ of the sows with a longer than normal oestrous cycle. In this latter group the accuracy of the diagnosis increased from $0 \%$ to $69 \%$ to $81 \%$ and to $91 \%$ on days $18-21$, $22-25,26-27$ and $28-29$ respectively.

Table 15.1 ACCURACY OF THE DIAGNOSIS OF PREGNANCY AND NON-PREGNANCY IN PIGS BY THE VAGINAL BIOPSY METHOD

\begin{tabular}{llll}
\hline Authors & $\begin{array}{l}\text { Time after } \\
\text { mating } \\
\text { (days) }\end{array}$ & \multicolumn{2}{c}{ Accuracy of diagnosis (\%) } \\
\cline { 2 - 4 } & $20-25$ & Pregnant & Non-pregnant \\
\hline Diehl and Day (1973) & $95.5(156)$ & $94.4(18)$ \\
Bosc, Martinat-Botte and Nicolle (1975) & $18-29$ & $96.7(573)$ & $71.5(144)$ \\
McCaughey (1979) & $17-22$ & $99.4(168)$ & $77.3(22)$ \\
\hline
\end{tabular}

Numbers in parentheses indicate number of animals cxamined 
The results show that vaginal biopsy can be used effectively as a means of pregnancy diagnosis. The tissue sample requires approximately two minutes to collect and identify. In practice the results are reported back to the producer within 48 hours of receipt at the laboratory. The technique is limited to the collection of samples close to the expected time of oestrus and as such the results are not generally available until after the sow would be expected in oestrus (McCaughey, 1979). The failure to detect all pregnant animals suggests an error in tissue sampling or that in some animals the sloughing of the epithelial cell layers does not proceed as fast as in others. The failure to detect all non-pregnant sows may be attributed to an extended dioestrous condition which could easily be mistaken for pregnancy. This could occur with a longer than normal luteal phase and with anoestrus. Although the earlier work reviewed by Walker (1972) indicated that an accurate diagnosis can be made after day 18 and up to at least day 90 , the potential for confusion of dioestrus and pregnancy suggests that the most accurate results can be obtained around the expected time of oestrus.

\section{BLOOD OESTROGENS}

The observation that the pregnant sow excretes large quantities of oestrogens in the urine was first demonstrated by Küst (1931). Since that time numerous methods have been developed to measure urinary oestrogen concentration as a means of confirming pregnancy. This research has been reviewed by Kawata and Fukui (1977). These earlier techniques of analysis were found to be of limited value because of the time involved in urine collection and analysis, the complexity and cost of the analysis, and the variability in the results that were obtained. The development of radioimmunoassays for oestrogens and the observations of Perry, Heap and Amoroso (1973) that the increase in oestrogen concentration was the result of production by the embryos has renewed interest in blood oestrogen analysis as a pregnancy diagnosis technique. Robertson and King (1974) reported that the initial increase in blood oestrogen concentration is apparent by day 16 of pregnancy and reaches an initial maximum ( $>3 \mathrm{ng}$ / $\mathrm{ml}$ ) between days 23 and 30 , followed by a decline to $35 \mathrm{pg} / \mathrm{ml}$ on day 46 and an increase to the maximum on the day before parturition. The initial peak in oestrogen concentration is almost entirely oestrone sulphate while the increase observed after day 46 is composed of similar quantities of oestrone and oestrone sulphate. The maximum concentration of oestrone on the day before parturition was sixteen-fold greater than that of oestradiol-17 $\beta$.

In view of these recent findings the analysis of blood for oestrone sulphate between days 23 and 30 of pregnancy and the analysis for oestrone and oestrone sulphate after day 70 should provide an accurate means of pregnancy diagnosis. The radioimmunoassay system used by Robertson and King (1974) was too complex for routine analysis. Recently Wright et al. (1978), Guthrie and Deaver (1979) and Saba and Hattersley (1981) have all developed radioimmunoassay procedures that are suitable for routine analysis. The assay procedure of Saba and Hattersley (1981) 
appears to have advantages over the others in that the assay is conducted directly on the blood serum sample and thus measures both oestrone and oestrone sulphate. They reported a reduction in accuracy of approximately $12 \%$ compared with oestrone sulphate alone. In 87 serum samples collected 26-28 days after mating the mean oestrone plus oestrone sulphate concentration was $2.7 \mathrm{ng} / \mathrm{ml}$. Eleven of these serum samples had less than $1.0 \mathrm{ng} / \mathrm{ml}$ of oestrone plus oestrone sulphate but none were less than $0.5 \mathrm{ng} / \mathrm{ml}$. In a comparable group of 28 non-pregnant sows, 21 of the sows had oestrone plus oestrone sulphate concentrations of less than $0.3 \mathrm{ng} / \mathrm{ml}$ while none of the sows had a concentration greater than $0.5 \mathrm{ng} / \mathrm{ml}$. Three of these latter blood samples were collected during oestrus.

The analysis of blood for oestrone sulphate appears to have sufficient accuracy to be an effective means of pregnancy diagnosis. However; more extensive field trials are required before an accurate assessment can be made. The observation by Guthrie and Deaver (1979) of an initial rise in oestrone concentration on day 22 for three animals with delayed luteolysis suggests late embryonic death which would have been detected and the sows diagnosed as non-pregnant. Similarly, sows with silent oestrus and anoestrous sows would be identified as non-pregnant. The major disadvantage of the assay is that the blood samples must be obtained after the expected time of oestrus. Potentially the only animals that would not be properly diagnosed are those with late embryonic death. In addition, the oestrone/oestrone sulphate analysis may be of value in determining litter size. Guthrie and Deaver (1979), Chew et al. (1979) and Horne and Dziuk (1979) all reported significant correlations between litter size and oestrone sulphate concentration. Further research is still needed to determine the accuracy of this estimate of litter size as approximately one third of the intrauterine death losses occur after day 25 (Dyck, 1974).

\section{RECTAL PALPATION}

The use of rectal examination to diagnose pregnancy was first described by Huchzermeyer and Plonait (1960). A detailed description of the procedure and the changes observed by palpation of the cervix and uterus throughout the oestrous cycle and pregnancy have been reported by Cameron (1977). The hand is passed through the anal ring at least $30 \mathrm{~cm}$ into the rectum and the cervix found below the rectum. After examination of the cervix and uterus, the middle uterine artery is detected where it crosses the external iliac artery. The external iliac artery appears to be about $1 \mathrm{~cm}$ in diameter while the middle uterine artery varies from $2-4 \mathrm{~mm}$ in diameter during the oestrous cycle. During pregnancy the middle uterine artery increases in size from about $5 \mathrm{~mm}$ at the end of the third week of pregnancy to more than $1 \mathrm{~cm}$ as pregnancy progresses beyond 60 days. During pregnancy a distinct fremitus is detected as a continuous pulse when compared with the normal pulse in the external iliac artery. The size of the artery and the condition of the pulse are both positive diagnostic criteria for pregnancy. Palpation of the uterus for the presence of embryos is not possible until late pregnancy. 
For the confirmation of pregnancy, rectal palpation has been found to have an accuracy approaching $100 \%$ after 28 days (Meredith, 1976). Accuracy of pregnancy diagnosis during the third and fourth weeks was $32 \%$ and $75 \%$, respectively. Other examples of the accuracy of diagnosing pregnancy and non-pregnancy are shown in Table 15.2.

Table 15.2 ACCURACY OF THE DIAGNOSIS OF PREGNANCY AND NON.PREGNANCY IN PIGS BY THE RECTAL PALPATION METHOD

\begin{tabular}{llll}
\hline Authors & $\begin{array}{l}\text { Time after } \\
\text { mating } \\
\text { (days) }\end{array}$ & \multicolumn{2}{l}{ Accuracy of diagnosis (\%) } \\
\cline { 3 - 4 } & $30-80$ (gits) & $80.6(636)$ & $29.7(60)$ \\
\hline Fritzsch and Hühn (1976) & $30-80$ (sows) & $89.0(1023)$ & $15.8(55)$ \\
Cameron (1977) & $21-30$ & $84.6(26)$ & $20.0(5)$ \\
& $31-60$ & $93.2(336)$ & $55.8(52)$ \\
Benjaminsen and Karlberg (1980) & $>60$ & $99.0(98)$ & $66.7(3)$ \\
& $30-60$ & $100.0(86)$ & $100.0(34)$ \\
\hline
\end{tabular}

Numbers in parentheses indicate number of animals examined.

Rectal palpation is most limited by the size of the pubic symphysis and thus the size of the palpator's hand. Huchzermeyer and Plonait (1960) recommended a minimum animal weight of $150 \mathrm{~kg}$ for ease of palpation. While most reports suggest that pregnancy diagnosis is not accurate before 30 days of pregnancy, Yamanouchi (1973) was able to detect the fremitus two weeks after service. Thus, it may be possible in some animals to confirm pregnancy before the next expected oestrus. The low accuracy of detecting non-pregnant animals in some of the reports suggests that a certain minimum experience is required which would not be possible with occasional palpations. The major advantages are an immediate diagnosis within a few minutes and a minimum of restraint of the animal.

\section{ULTRASONIC ANALYSES}

Ultrasonic techniques of pregnancy diagnosis are based either on foetal heart rate and the foetal pulse (Doppler ultrasound), or the detection of foetal fluids in the uterus (A-mode or amplitude-depth ultrasound). Thus, both tests identify the products of conception and are potentially more accurate for the confirmation of pregnancy than techniques based on secondary effects of conception or oestrous activity.

\section{Doppler techniques}

The Doppler ultrasound technique, as described by Fraser and Robertson (1967), is based on the alteration of the reflected signal as a result of movement within the body and detected as sounds heard through earphones, loudspeaker or visible signal on an oscilloscope. While various sounds may be heard it is easy to detect differences in pulse rate and those of the foetus and mother can be differentiated. The foetal heart rate was 
found by Too et al. (1974) to be 2-3 times the maternal heart rate with the difference decreasing as pregnancy progressed. Using a transducer applied on the skin of the lower abdomen or flank Too et al. (1974) determined the accuracy of pregnancy diagnosis from 22 to 114 days of gestation. In the period between days 22 to 39 of pregnancy confirmation was $68 \%$ correct while after 40 days the accuracy was $100 \%$. Pierce, Middleton and Phillips (1976) used an intrarectal transducer and were able to detect the foetal heart beat 19 days after mating although not all animals were correctly diagnosed as pregnant until 34 days after mating. Recently, Benjaminsen and Karlberg (1980) reported a $94 \%$ accuracy in confirming pregnancy and a $96 \%$ accuracy in detecting non-pregnant sows 30 to 60 days after mating.

\section{Amplitude-depth techniques}

The A-mode (amplitude-depth) ultrasonic technique as described by Lindahl et al. (1975) is similar to the Doppler technique except that it detects an echo from the fluid-filled uterus. The external transducer is placed against the abdominal wall in the area of the flank and in the direction of the uterus. Using an oscilloscope to detect the reflected signal they found that non-pregnant sows produced signals only to a depth of $5 \mathrm{~cm}$. Pregnant animals produced signals at a depth of $15-20 \mathrm{~cm}$. O'Reilly (1976) using 686 pregnant animals found a 55\% accuracy in confirming pregnancy between 0 and 30 days after mating, $98 \%$ from 31 to 90 days and $84 \%$ from 91 days to term. In a group of 69 non-pregnant animals $81 \%$ were correctly diagnosed. Lindahl et al. (1975) reported a 99\% accuracy in diagnosing pregnancy in a group of 801 sows and an accuracy of $98 \%$ in diagnosing 189 of these sows as non-pregnant. In a field survey on 21000 animals the accuracy of diagnosing non-pregnant sows was greater than 95\%. A similarly high degree of accuracy was reported by Hansen and Christiansen (1976) with 96 observations on 70 sows. Sixty-two observations were correctly diagnosed as pregnant and 31 observations correctly diagnosed as non-pregnant. The remaining three observations on two sows were incorrectly diagnosed as pregnant due to an abnormal accumulation of fluid in the uterus. In contrast to these results, Benjaminsen and Karlberg (1980) reported an $89 \%$ accuracy in confirming pregnancy in 116 sows and a $56 \%$ accuracy in detecting 63 non-pregnant sows.

The accuracy of ultrasonic pregnancy diagnosis appears to be most limited by the ability of the operator to properly place and direct the transducer towards the uterus. For the Doppler technique experience in differentiating the specific sounds received also is required. Errors in placement of the A-mode transducer may result in the detection of a fluid-filled bladder which would give false positive results or conversely miss the uterus entirely and thus produce false negative results. The technique however provides immediate results without requiring the assistance of specially trained personnel although accurate results for the diagnosis of non-pregnant animals are often not possible before 40-60 days of pregnancy. The large number of commercially available A-mode units may make the selection of the most desirable unit difficult. 


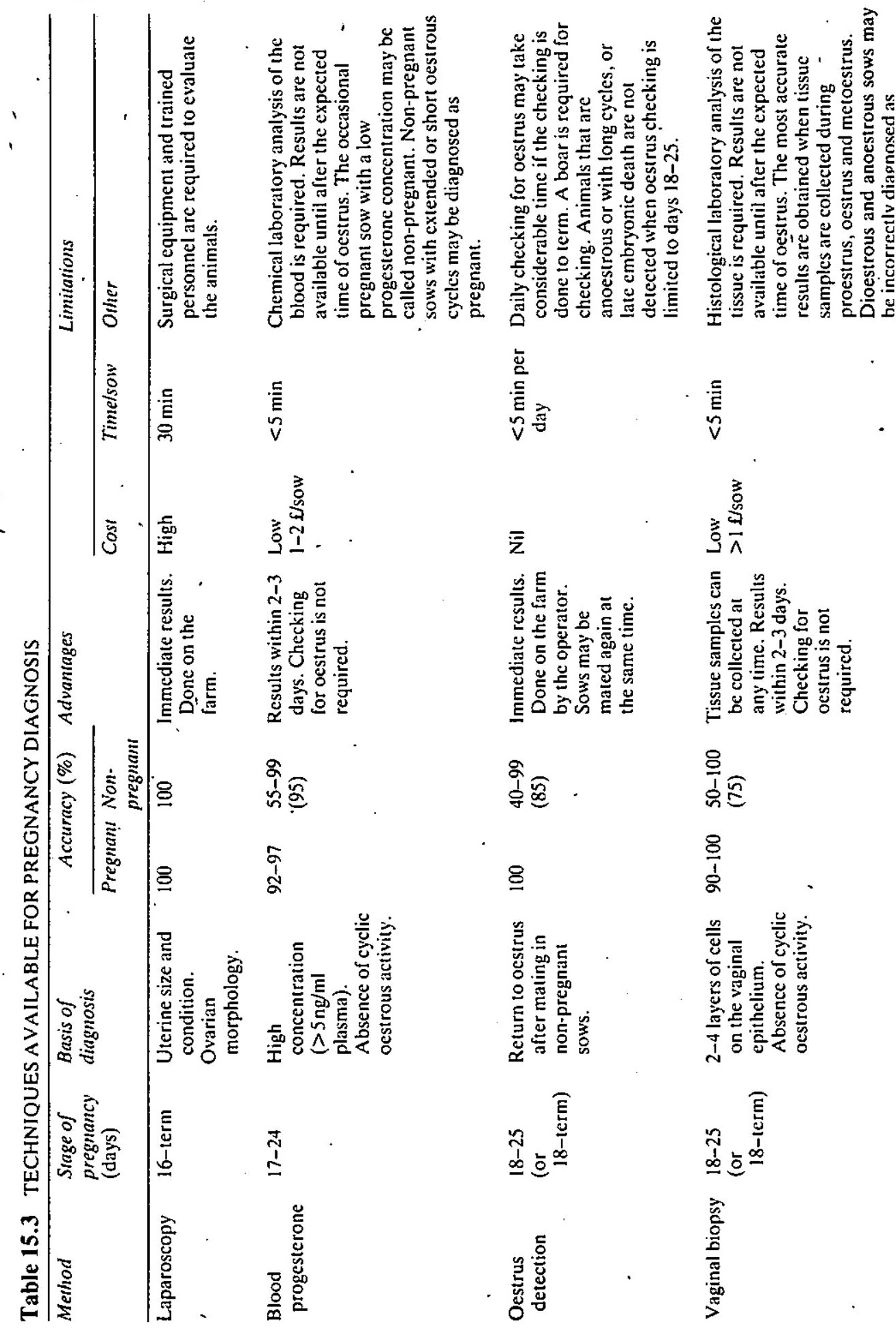




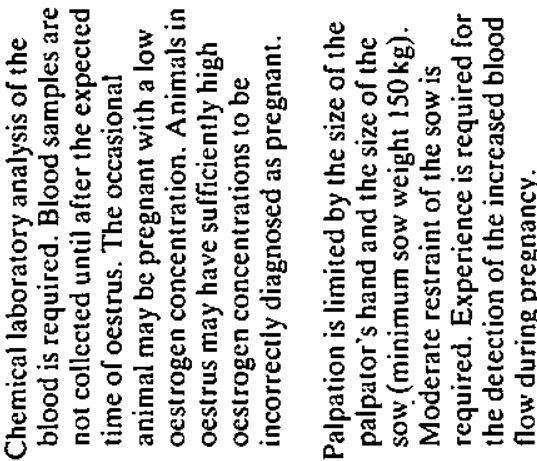
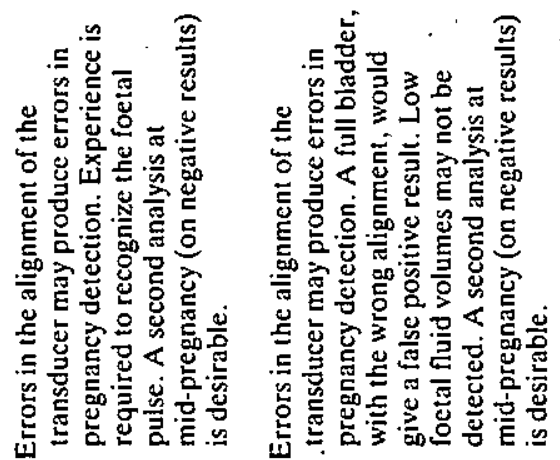

气

들

产

$\stackrel{E}{E}$
$\mathscr{V}$

3
0
3
3

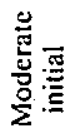

总

i

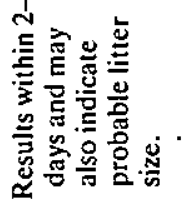

文
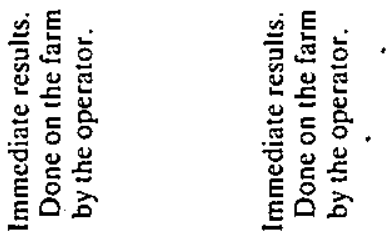

ํㅜㅅ

유ㅇㅛㅛ

2
2
2

ํํ의

$\stackrel{n}{\wedge}$

호옹

ลั่

à

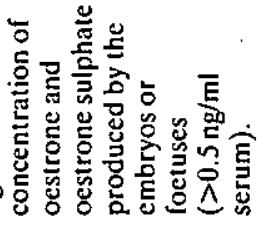

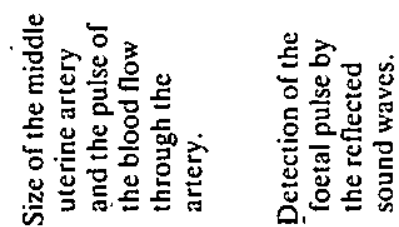

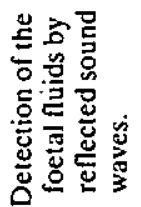

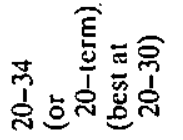

竧

톤

$\infty$
1
1
p

范

焉

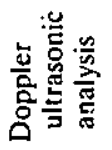

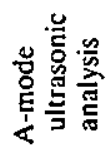




\section{Conclusion}

This chapter has been directed towards an evaluation of the current status of our ability to accurately detect pregnant and non-pregnant sows from the time of mating to parturition. It has not been the intention of this review to recommend specific techniques in preference to others, but rather to highlight the advantages and limitations of the various methods. At the present time there is no accepted accurate method of determining the reproductive status of the pig from the time of mating to the expected time of embryo implantation. The measurement of immunosuppressive activity may provide an acceptable means of very early pregnancy diagnosis. During the early stages of embryonic growth (days 13-15) the determination of blood prostaglandin levels may also provide an accurate means of early pregnancy diagnosis. The major emphasis on pregnancy diagnosis has been directed at the embryonic and early foetal stage of development. The problem has been to accurately identify the small proportion of sows that fail to become pregnant after mating. This group usually comprises about $5 \%$ of the sows mated and may occasionally be in excess of $20 \%$ in some herds. The difficulties arise because of the variability of the reasons for the failure of conception. Thus, while any one diagnostic procedure will detect sows that are not pregnant for one or more reasons, it will not provide accurate results for all causes of conception failure. These observations are summarized in Table 15.3.

The variety of techniques developed for the confirmation of pregnancy and the detection of the non-pregnant sow after the beginning of implantation emphasizes the extent of the research that has been undertaken. The techniques of laparoscopy, oestrous detection, vaginal biopsy and rectal palpation appear to have been fully developed. However, in the use of ultrasonic techniques, further refinement of the electronics to discriminate among the signals received and the sensitivity of the receiver may be anticipated. These advances should shorten the time interval from mating to detection of pregnancy. The determination of blood concentrations of progesterone and oestrone sulphate may be developed to allow on-farm evaluation utilizing 'test-tube' analysis procedures.

\section{References}

BAZER, F.W. and THATCHER, W.W. (1977). Theory of maternal recognition of pregnancy in swine based on estrogen controlled endocrine versus exocrine secretion of prostaglandin $F_{2 \alpha}$ by the uterine endometrium. Prostaglandins 14, 397-401

BENJAMINSEN, E. and KARLBERG, K. (1980). Pregnancy examination in the sow: A comparison of two types of ultrasound equipment and rectal examination. Nord. VetMed. 32, 417-422

BOSC, M.J., MARTINAT-BOTTE, F. and NICOLLE, A. (1975). Étude de deux technique de diagnostic de gestation chez la Truie. Annls. Zootech. 24, $651-660$

CAMERON, R.D.A. (1977). Pregnancy diagnosis in the sow by rectal examination. Aust. vet. J. 53, 432-435 
CHEW, B.P., DZIUK, P.J., THOMFORD, P.J. and KESLER, D.J. (1979). Relationships between blood estrone sulfate and fetal number in gilts between days 22 and 80 of pregnancy. Proc. 71st Ann. Meeting, Am. Soc. Anim. Sci., p.285 (Abstract No. 356)

CIUREA, V., NEUMANN, F., PASTEA, Z. and OLARIAN, E. (1955). Diagnosticul histologic al gestatiei la scroafa-Acad. R.P.R. Baza Timisoara, Ann. II (Seria 2) 113. Quoted by Kawata and Fukui (1977)

DHINDSA, D.S. and DZIUK, P.J. (1968). Effect on pregnancy in the pig after killing embryos or fetuses in one uterine horn in early gestation. $J$. Anim. Sci. 27, 122-126

DICKMANN, Z., DEY, S.K. and SEN GUPTA, J. (1976). A new concept: Control of early pregnancy by steroid hormones originating in the preimplantation embryo. Vitams. Horm. 34, 215-242

DIEHL, J.R. and DAY, B.N. (1973). Utilization of frozen sections with the vaginal biopsy technique for early pregnancy diagnosis in swine. $J$. Anim. Sci. 37, 114-117

DYCK, G.W. (1971). Puberty, post weaning estrus and estrous cycle length in Yorkshire and Lacombe swine. Can. J. Anim. Sci. 51, 135-140

DYCK, G.W. (1974). The effects of stage of pregnancy, mating at the first and second estrus after weaning and level of feeding on fetal survival in sows. Can. J. Anim. Sci. 54, 277-285

EVINSON, B., NANCARROW, C.D., MORTON, H., SCARAMUZZI, R.J. and CLUNIE, J.A. (1977). Detection of early pregnancy and embryo mortality in sheep by the rosette inhibition test. Theriogenology 8, 157 (Abstract)

ELLICOT, A.R. and DZIUK, P.J. (1973). Minimum daily dose of progesterone and plasma concentration for maintenance of pregnancy in ovariectomized gilts. Biol. Reprod. 9, 300-304

FRASER, A.F. and ROBERTSON, J.G. (1967). The detection of foetal life in ewes and sows. Vet. Rec. 80, 528-529

FRITZSCH, Von $M$. and HÜHN, U. (1976). Untersuchungen zur rektalen trächtigkeitsdiagnostik bei jung-und Altsauen vom 30 . bis 80 . tag post inseminationem. Mh. Vet. Med. 31, 569-571

GUTHRIE, H.D. and DEAVER, D.R. (1979). Estrone concentration in the peripheral plasma of pregnant and non-pregnant gilts. Theriogenology 11, 321-329

HANSEN, L.H. and CHRISTIANSEN, Ib. J. (1976). Frühe trächtigkeitsdiagnose beim schwein mit eimen neuentwickelten ultraschall-A-skan-gerät. Zuchthygiene 11, 19-21

HORNE, C. and DZIUK, P.J. (1979). Relationship between level of estrone sulfate and number of fetuses in gilts from day 10 to 32. Proc. 71st Ann. Meeting, Am. Soc. Anim. Sci., pp. 304-305 (Abstract No. 403)

HUCHZERMEYER, F. and PLONAIT, H. (1960). Trächtigkeitsdiagnose und rectaluntersuchung beim schwein. Tierärzll. Umsch. 15, 399-401

HUNTER, R.H.F., POLGE, C. and ROWSON, L.E.A. (1967). The recovery, transfer and survival.of blastocysts in pigs. J. Reprod. Fert. 14, 501-502

JÖCHLE, W. and SCHILLING, E. (1965). Improvement of conception rate and diagnosis of pregnancy in sows by an androgen-oestrogen-depot preparation. J. Reprod. Fert. 10, 439-440

KAWATA, K. and FUKUI, Y. (1977). Pregnancy diagnosis in the pig: A review. Folia Vet. Lat. 7, 91-110 
KÜST, D. (1931). Die trächtigkeitsfeststellung bei unseren haustieren durch den nachweis dis sexualhormons in harn. Dt. tierarztl. Wschr. 39,738-741

LINDAHL. I.L., TOTSCH, J.P., MARTIN, P.A. and DZIUK, P.J. (1975). Early diagnosis of pregnancy in sows by uitrasonic amplitude-depth analysis. $J$. Anim. Sci. 40, 220-222

McCAUGHEY, w.J. (1979). Pregnancy diagnosis in sows: A comparison of the vaginal biopsy and doppler ultrasound techniques. Vet. Rec. 104, 255-258

McKENZIE, F.F. (1924). Correlations of external signs and vaginal changes with the ovarian cycle in swine. Anat. Rec. 27, 185-186

MACNEIL, F. (1979). Blood testing for pregnancy. Pig Fmg. September, 40-43

MARTINAT-BOTTE, F., GAUTIER, J., DEPRES, P. and TERQUi, M. (1980). Application d'un diagnostic très précoce de gestation en élevage porcin. Journées de la Recherche Porcine en France, pp. 167-170. Paris, L'Institut Technique du Porc

MEREDITH, M.J. (1976). Pregnancy diagnosis in the sow by examination of the uterine arteries: Proc. 4th Int. Congr. Pig Veterinary Society, Ames, Iowa, U.S.A. p.D.5

MEYER, J.N., ELSASSER, F. and ELLENDORFF, F. (1975). Trächtigkeits und fertilitätstest beim schwein mit hilfe der plasma progesteronbestimmung. Dt. tierärztl. Wschr. 12, 473-475

MORTON, D.B. and RANKIN, J.E.F. (1969). The histology of the vaginal epithelium of the sow in oestrus and its use in pregnancy diagnosis. Vet. Rec. 84, 658-662

MORTON, H., HEGH, V. and CLUNIE, C.J.A. (1976). Studies of the rosette inhibition test in pregnant mice: evidence of immunosuppression? Proc. Roy. Soc., Lond. B193, 413-419

NANCARROW, C.D., QUINN, P.J., RIGBY, N.W., WALLACE, A.L.C. and GREWAL, A.S. (1980). Involvement of the zygote, oviduct and ovary in the production of an early pregnancy factor in sheep. Biol. Reprod. 22 (Suppl. 1), 28A (Abstract)

NISHIKAWA, Y. (1953). A method of early pregnancy diagnosis and detection of luteal phase in domestic animals by injection of synthetic estrogen "euvestin". Suikai (The Veterinary World) 30, 8-11

O'REILLY, P.J. (1976). Pregnancy diagnosis in pigs by ultrasonic amplitude depth analysis - A field evaluation. Ir. vet. J. 24, 165-167

PÁSZTOR, L. and TÓTH, S. (1964). Data on the oestrous cycle of the sow. Kisérl. Közl. Allatten. 57 B, 105-109. (In Anim. Breed. Abstr. 35, 122, 1967.)

PERRY, J.S., HEAP, R.B. and AMOROSO, E.C. (1973). Steroid hormone production by pig blastocysts. Nature, Lond. 245, 45-47

PIERCE, J.E., MIDDLETON, C.C. and PHILLIPS, J.M. (1976). Early pregnancy diagnosis in swine using doppler ultrasound. Proc. 4th Int. Congr. Pig Veterinary Society, Ames, Iowa, U.S.A., p.D.3

ROBERTSON, H.A. and KING, G.J. (1974). Plasma concentrations of progesterone, oestrone, oestradiol-17 $\beta$ and of oestrone sulphate in the pig at implanation, during pregnancy and at parturition. J. Reprod. Fert. 40, 133-141

ROBERTSON, H.A. and SARDA, J.R. (1971). A very early pregnancy test for 
mammals: Its application to the cow, ewe and sow. J. Endocr. 49, 407-419

SABA, N. and HATTERSLEY, J.P. (1981). Direct estimation of oestrone sulphate in sow serum for a rapid pregnancy diagnosis test. J. Reprod. Fert. 62, 87-92

SIGNORET, J.P. (1967). Durée du cycle oestrien et de l'oestrus chez la truie. Action du benzoate d'oestradiol chez la femelle ovariectomizée. Annls. Biol. anim. Biochim. Biophys. 7, 407-421

SIGNORET, J.P. (1970). Reproductive behavior of pigs. J. Reprod. Fert. Suppl. 11, 105-117

STABENFELDT, G.H., AKINS, E.L., EWING, L.L. and MORRISSETTE, M.C. (1969). Peripheral plasma progesterone levels in pigs during the oestrous cycle. J. Reprod. Fert. 20, 443-449

TILLSON, S.A., ERB, R.E. and NISWENDER, G.D. (1970). Comparison of luteinizing hormone and progesterone in blood and metabolites of progesterone in urine of domestic sows during the estrus cycle and early pregnancy. J. Anim. Sci. 30, 795-805

TOO, K., KAWATA, K., FUKUI, Y., SATO, K., KAGOTO, K. and KAWABE, K. (1974). Studies on pregnancy diagnosis in domestic animals by an ultrasonic doppler method: I. Pregnancy diagnosis in the pig and fetal heart rate changes during pregnancy. Jap. J. vet. Res. 22, 61-71

WALKER, D. (1972). Pregnancy diagnosis in pigs. Vet. Rec. 90, 139-144

WILDT, D.E., FUJIMOTO, S., SPENCER, J.L. and DUKELOW, 'W.R. (1973). Direct ovarian observation in the pig by means of laparoscopy. J. Reprod. Fert. $35,541-543$

WILDT, D.E., MORCOM, C.B. and DUKELOW, W.R. (1975). Laparoscopic pregnancy diagnosis and uterine fluid recovery in swine. J. Reprod. Fert: 44, 301-304

WILLIAMSON, P., HENNESSEY, D.P. and CUTLER, R. (1980). The use of progesterone and oestrogen concentrations in the diagnosis of pregnancy, and in the study of seasonal infertility in sows. Aust. J. agric. Res. 31, 233-238

WILSON, K.M. (1926). Histological changes in the vaginal mucosa of the sow in relation to the oestrous cycle. Am. J. Anat. 37, 417-430

WRIGHT, K., COLLINS, D.C. MUSEY, P.I. and PREEEDY, J.R.K. (1978). A specific radioimmunoassay for estrone sulfate in plasma and urine without hydrolysis. J. clin. Endocr. Metab. 47, 1092-1098

YAMANOUCHI, G. (1973). Rectal examination in the pig: Pregnancy diagnosis and palpation of the ovary. Jui-chikusam Shimpo (J. Vet. Med.) $\mathbf{5 8 5}$, 203-207 